\title{
THERMODYNAMIC SUBSTANTIATION OF INTEGRAL MECHANISMS OF MICROBIAL INTERACTION WITH METALS
}

\author{
Vira Hovorukha, Olesia Havryliuk, Hanna Tashyreva, Oleksandr Tashyrev, Iryna Sioma
}

\begin{abstract}
Despite the promising application of microorganisms for purification of metal-containing wastewater such biotechnologies have not been widely used since their empirical basis. Therefore, the aim of our work was to apply thermodynamic prognosis to determine the optimal pathway of microbial removal of toxic metals $\left(\mathrm{CrO}_{4}{ }^{2-}, \mathrm{Cu}^{2+}\right)$ and its experimental justification. There was theoretically substantiated on the base of thermodynamic prognosis and experimentally confirmed integration of microbial reduction of metals, and their precipitation by microorganisms. Developed approach is the methodological basis for fast and effective purification of metal-containing wastewater.
\end{abstract}

Key words: thermodynamic prognosis, toxic metals, wastewater, metal reduction, metal precipitation.

\section{INTRODUCTION}

The level of environment pollution with heavy metals is constantly increasing. The global use of metal-containing raw materials in industry, medicine and agriculture has led to wide pollution of environment with toxic metals [37]. That is why the ecological safety of the environment is one of the prior directions of modern science. Sewage water from industrial enterprises is one of the most polluted with toxic metals in the environment. There are metallurgical engineering, electroplating, tanning and textile industry, preservation of wood, watercooling and chromate preparation [12]. The routine methods for industrial waste purification from heavy metal are cementation, precipitation, ion exchange, electro-dialysis, electro-winning, electro-coagulation and reverse osmosis [1]. These technologies are often low-efficiency, expensive and also can't access necessary level of wastewater purification from heavy metals in high concentration. According to these disadvantages development of novel more efficient technologies is absolutely necessary [8]. Immobilization of heavy metals by microorganisms and reduction of metals to insoluble compounds are the most effective, low-cost and ecologically friendly methods of sewage treatment. There are various biotechnological methods for purification of industrial wastewater from $\mathrm{Cr}(\mathrm{VI})$ and $\mathrm{Cu}^{2+}$, which are based on their accumulation and reduction to insoluble compounds by microorganisms [7, 17, 30, 25].

Determination of mechanisms of microbial interaction with toxic metals has both fundamental and practical importance. The fundamental one is thermodynamic justification of optimal pathway of microbial interaction with metals that leads to their extraction from water solution (wastewater). The practical importance is development of novel effective environmental biotechnologies for purification of sewage from toxic metals. Such metals as chromium and copper are widespread toxic environmental pollutants $[19,11]$. Anion of $\mathrm{CrO}_{4}{ }^{2-}$ is a metal-oxidizer
[36]. It irreversibly oxidizes components of microbial cell and blocks its electron transporting chain. Cation of $\mathrm{Cu}^{2+}$ is a metal of combined action. It oxidizes microbial cell components and also it substitutes macroelements in cell wall and in the active centers of enzymes [36]. That is why they are very toxic for microorganisms and dangerous for environment generally $[32,3,18]$.

Thus, the aim of our work was to apply thermodynamic prognosis to determine the optimal pathway of microbial removal of toxic metals $\left(\mathrm{CrO}_{4}{ }^{2-}, \mathrm{Cu}^{2+}\right)$ and its experimental justification.

\section{MATERIALS AND METHODS}

Thermodynamic prognosis of microbial interaction with compounds of chromium and copper.

Prognosis of interaction of microorganisms with chromium and copper compounds was carried out on the basis of Pourbaix diagrams of the state of elements in the $\mathrm{pH}$-Eh coordinates [28]. On its basis, the stability fields of metals in aqueous solutions were calculated, and the optimal metabolic pathways of microbial interaction with metals, leading to their rapid and efficient extraction from solutions, were determined.

Cultivation of microorganisms in the presence of toxic metals.

\section{Preparation of the inoculum.}

The community of hydrogen-synthesizing soil microorganisms was used as an inoculum. To obtain it, 50 grams of diced potatoes (the length of cube rib $-1 \mathrm{~cm}), 5 \mathrm{~g}$ of soil and $100 \mathrm{ml}$ of boiled and cooled tap water were added to a $250 \mathrm{ml}$ vial. The mixture was pasteurized for 10 minutes in a water bath at temperature of $75^{\circ} \mathrm{C}$. After that, the vial was hermetically sealed with an elastic rubber stopper and a metal seal. Microorganisms were cultured during 5 days $\left(\mathrm{t}=30^{\circ} \mathrm{C}\right)$. Increase in the volume of gas and appearance of $\mathrm{H}_{2}$ in the gas phase evidenced the development of hydrogensynthesizing microorganisms. Further, community of hydrogen-synthesizing microorganisms was used as an inoculum to study the patterns of microbial interaction with metals. 
Study of the patterns of microbial growth in the presence of toxic metals.

The vials (volume $500 \mathrm{ml}$ ) were filled with $300 \mathrm{ml}$ of tap water, $50 \mathrm{~g}$ of model mixture of food waste (diced raw potatoes and meat in an equal weight ratio) and $5 \mathrm{ml}$ of inoculum of anaerobic hydrogen-synthesizing microorganisms. Toxic metals were added at the following concentrations: $\mathrm{CrO}_{4}{ }^{2-}-5000 \mathrm{ppm}, \mathrm{Cu}^{2+}$ $10000 \mathrm{ppm}$. Cultivation was carried out during 15 days $\left(\mathrm{t}=30^{\circ} \mathrm{C}\right)$. The growth of microorganisms was determined by decrease in the redox potential (Eh) of the medium, change the $\mathrm{pH}$, increase in the optical density of the medium, decrease in the concentration of $\mathrm{CrO}_{4}{ }^{2-}$ and $\mathrm{Cu}^{2+}$, and also increase in the concentration of $\mathrm{CuCO}_{3}$.

The $\mathrm{pH}$ and $\mathrm{Eh}$ of the culture liquid was measured by the potentiometric method with the $\mathrm{pH}$-metermillivoltmeter "pH-150 MA". The measuring electrode ЭСК-10603/4 was used to determine the $\mathrm{pH}$. Redoxpotential was measured using platinum measuring electrode ЭПВ-1. The silver chloride electrode ЭВЛ$1 \mathrm{M} 3$ was used as reference.

Biomass growth was determined by optical density of the cell suspension by the photoelectrocolorimeter (PEC) at $\lambda=540 \mathrm{~nm}$ and $0,5 \mathrm{~cm}$ of an optical path length.

Determination of $\mathrm{CrO}_{4}^{2-}$ concentration was carried out by the colorimetric method, which is based on the appearance of crimson color interacting with diphenylcarbazide (DPC). A centrifuged culture liquid ( $2 \mathrm{ml}), 0.5 \mathrm{ml}$ of $\mathrm{H}_{2} \mathrm{SO}_{4}(1: 3)$ and $0.5 \mathrm{ml}$ of DPC were added into the tube. The sensitivity of the method is $1 \mathrm{ppm}$. Optical density of solution was measured by the photoelectrocolorimeter (PEC) at $\lambda=500 \mathrm{~nm}$ and $0.5 \mathrm{~cm}$ of an optical path length [15].

To determine the concentration of $\mathrm{Cu}^{2+}$, PAR (4(2-pyridylazo)-resorcinol) was used. The sensitivity of the method is $1 \mathrm{ppm}$. Optical density of solution was measured by the photoelectrocolorimeter (PEC) at $\lambda=500 \mathrm{~nm}$ and $0.5 \mathrm{~cm}$ of an optical path length [29].

To determine the concentration of $\mathrm{CuCO}_{3}, 3 \mathrm{ml}$ of a suspension (culture liquid) containing microbial biomass and insoluble $\mathrm{CuCO}_{3}$ was taken from the vial with a syringe through a stopper and transferred to an analytical tube. Then $0.1 \mathrm{ml}$ of $1 \mathrm{~N} \mathrm{HCl}$ was added to the tube to dissolve copper carbonate to form $\mathrm{Cu}^{2+}$ cation. Further, the concentration of $\mathrm{Cu}^{2+}$ was determined using PAR [29].

\section{RESULTS AND DISCUSSION}

The high values of the redox potential of the oxidation-reducing systems they form are the factors determining toxicity of metals [36]. In neutral conditions $(\mathrm{pH}=7.0)$ water is stable in the range of standard values of the redox potential $E_{o}{ }^{\prime}$ from -414 to $+814 \mathrm{mV}$ (Fig. 1). The upper limit of water stability is determined by the reversible oxidation reaction of water oxygen to molecular oxygen: $2 \mathrm{H}_{2} \mathrm{O}=\mathrm{O}_{2}+4 \mathrm{H}^{+}+4 \overline{\mathrm{e}} ; E_{o}^{\prime}=+814 \mathrm{mV}$. The lower limit of water stability is determined by the reversible reaction of proton reduction to molecular hydrogen: $2 \mathrm{H}^{+}+2 \overline{\mathrm{e}}=\mathrm{H}_{2} ; E_{o}{ }^{\prime}=-414 \mathrm{mV}$ [36]. It follows that water has the properties of a binary redox buffer that is stable in the range of the standard redox potentials from -414 to $+814 \mathrm{mV}$.

Consequently, all redox reactions of energy and constructive metabolism of microorganisms are possible only in this range. Fig. 1a shows the redox potentials of seven reactions of chromium compounds reduction. Reaction No. 1 is outside the upper limit of the stability of water, and therefore it cannot be carried out by microorganisms. It is obvious that addition of $\mathrm{HCrO}_{4}{ }^{-}$into the culture medium with an extremely high redox potential, $\mathrm{Eh}=+1200 \mathrm{mV}(\mathrm{pH}=2.0)$, will lead to irreversible oxidation of the structural components and enzymes of microorganisms. This will lead to the death of microorganisms.

Reactions No. 5, 6, and 7 have redox potentials, more electro negative than the lower limit of water stability. Therefore, redox enzymes of microorganisms with higher potentials cannot reduce $\mathrm{Cr}^{3+}, \mathrm{Cr}^{2+}$ and $\mathrm{Cr}(\mathrm{OH})_{3}$. Moreover, these chromium compounds are reducing agents regarding to the proton of water, that inevitably leads to the reduction of the proton to molecular hydrogen.

Hence it follows that reactions No. 2, 3 and 4 are thermodynamically acceptable for microorganisms, since they are inside the field of thermodynamic stability of water. The reaction No. 4 is the most suitable for biotechnologies since only this reaction leads to insoluble product of microbial reduction of chromate - chromium(III) hydroxide $-\mathrm{Cr}(\mathrm{OH})_{3} \cdot \mathrm{nH}_{2} \mathrm{O}$. This reaction provides the removal of chromium compounds from solution.

Similar regularities are also inherent in oxidized copper compounds (Fig. 1b). The potentials of $\mathrm{Cu}^{2+}$ reduction reactions (reactions No. 8-14) are inside the water stability zone, and therefore it is theoretically permissible to reduce copper compounds by microorganisms.

Thermodynamic prognosis allows determining the conditions for reduction of copper by microorganisms, as well as the final products of the reactions. Thus, in the range of acidic values, $\mathrm{pH}=0.0-5.0, \mathrm{Cu}^{2+}$ cation will be reduced by microorganisms to insoluble compounds $\left(\mathrm{Cu}_{2} \mathrm{O}\right.$ and $\left.\mathrm{CuO}\right)$. These reactions lead to positive environmental effect - microbial removal of copper from solutions (sewage). 

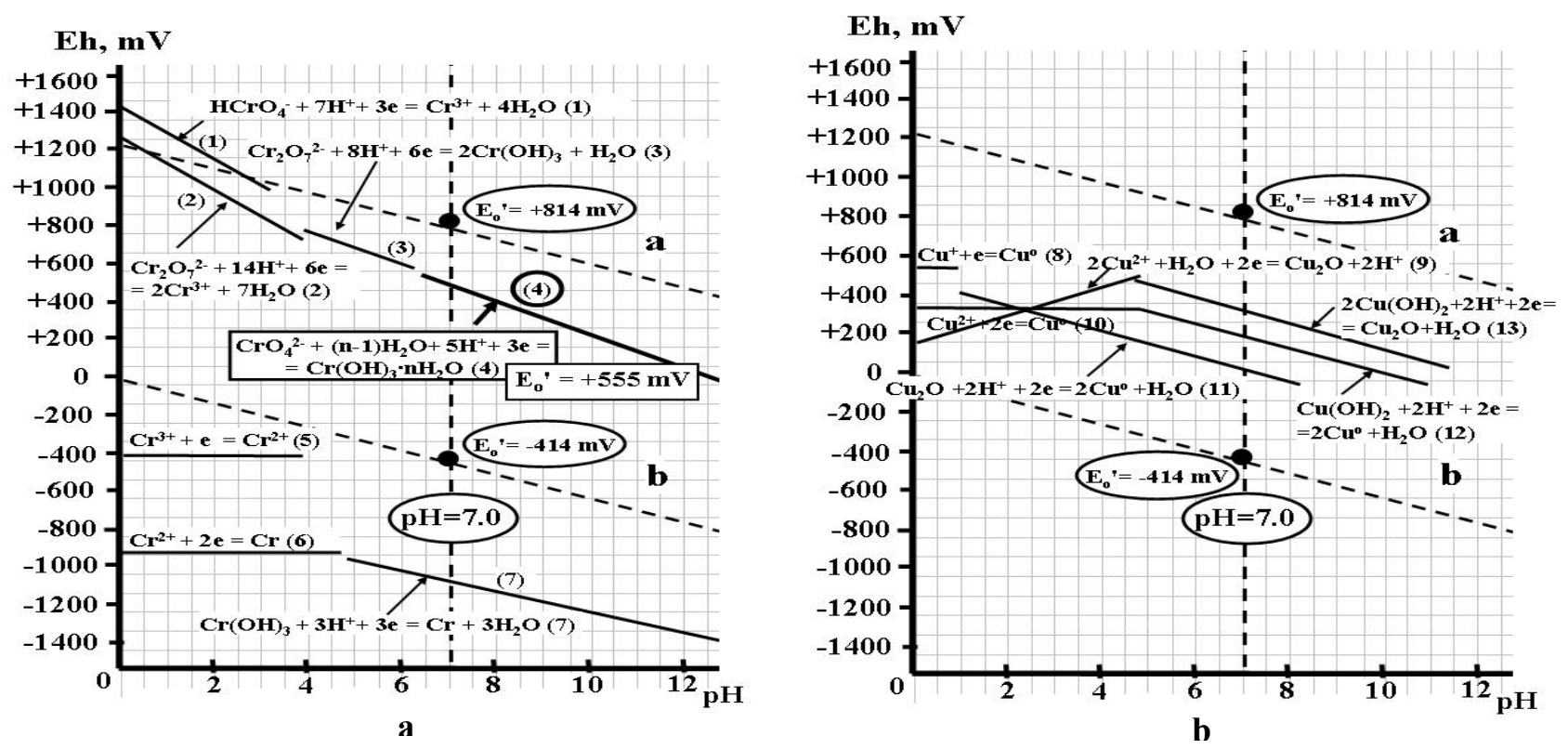

Fig. 1. Thermodynamic prognosis of microbial interaction with metals: $\mathrm{a}$ - chromium compounds; $\mathrm{b}$ - copper compounds

Removal of copper from solutions is possible not only due to the reduction reactions, but also due to biologically mediated alkalinisation of the medium. Thus, at $\mathrm{pH}>5.0$ (Fig. 1b), $\mathrm{Cu}^{2+}$ cation is transformed into insoluble copper hydroxide $-\mathrm{Cu}(\mathrm{OH})_{2}$. Increase in $\mathrm{pH}$ of culture medium leading to the formation of $\mathrm{Cu}(\mathrm{OH})_{2}$ is possible, at least due to the two metabolic pathways. The first one is dissimilatory denitrification, in which Nitrogen of nitrate is reduced to $\mathrm{N}_{2}$, and the alkaline metal cation is accumulated in the medium $\left(\mathrm{Na}^{+}+\mathrm{NO}_{3}{ }^{-} \rightarrow \mathrm{Na}^{+}+\mathrm{N}_{2}\right)$, and the $\mathrm{pH}$ shifts to the alkaline conditions [20]. The second pathway is the cleavage of amino groups in the proteins by ammonifying bacteria, followed by the accumulation of alkaline Nitrogen compounds $\left(\mathrm{NH}_{2}-\mathrm{CH}_{2}-\mathrm{COOH}\right.$ $\rightarrow \mathrm{CH}_{3}-\mathrm{COOH}^{-}+\mathrm{NH}_{4}{ }^{+}, \mathrm{NH}_{4} \mathrm{OH}$ and $\left.\mathrm{NH}_{3}\right)[38,33]$. These two metabolic pathways lead to alkalization of the medium to $\mathrm{pH}$ values of 7.8-8.2. Obviously, under such alkaline conditions, the cation $\mathrm{Cu}^{2+}$ will inevitably precipitate $-\mathrm{Cu}(\mathrm{OH})_{2}$. It is necessary to mention the third biologically mediated pathway of copper precipitation - the formation of insoluble copper carbonate $-\mathrm{CuCO}_{3}$. Carbon dioxide is common end product of the metabolism of all chemoorganotrophic microorganisms [14]. Dissolved $\mathrm{CO}_{2}$ dominates under acidic conditions, a mixture of $\mathrm{CO}_{2}$ and $\mathrm{HCO}_{3}{ }^{-}$in neutral conditions, and $\mathrm{CO}_{3}{ }^{2-}$ in the alkaline ones [14]. Insoluble copper carbonate $\mathrm{CuCO}_{3}$ is formed during the interaction of $\mathrm{Cu}^{2+}$ cation with $\mathrm{CO}_{3}{ }^{2-}$ anion.

Thus, thermodynamic prognosis allows theoretically substantiating the determination of any type of microbial interaction with the cation $\mathrm{Cu}^{2+}$, leading to the removal of copper compounds from solutions (sewage).

Prognosis also makes it possible to significantly improve the efficiency of microbial copper removal by integrating at least two types of interaction. For example, when microorganisms use protein compounds (amino acids) as carbon and energy sources, the redox potential will be decreased to negative values $(-100 \ldots-300 \mathrm{mV})$, as well as alkaline cations will be accumulated due to deamination of amino acids. Thus, the efficiency of removal of $\mathrm{Cu}^{2+}$ cation will be increased both due to its reduction to insoluble $\mathrm{Cu}_{2} \mathrm{O}$ and $\mathrm{Cu}^{\circ}$, and due to the formation of insoluble $\mathrm{Cu}(\mathrm{OH})_{2}$ and $\mathrm{CuCO}_{3}$ due to alkalization of the medium (Fig. 1b).

It is obvious that in binary reactions of reduction of oxidized compounds of copper and chromium, metals function as electron acceptors. Organic compounds (sources of carbon and energy) are donors of electrons. Microorganisms act as biocatalysts. In our opinion, it is advisable to consider the sources of carbon (energy) and microorganisms as a donor system.

All the dissimilative biochemical reactions carried out by microorganisms have a redox potential specific for them.

For example, for nitrate reduction $\left(\mathrm{C}_{6} \mathrm{H}_{12} \mathrm{O}_{6}+4.8\right.$ $\left.\mathrm{NO}_{3}^{-}+4.8 \mathrm{H}^{+}=6 \mathrm{CO}_{2}+2.4 \mathrm{~N}_{2}+8.4 \mathrm{H}_{2} \mathrm{O}[2]\right)$ the redox potential determined by cytochromes is about $+200 \ldots+300 \mathrm{mV}$ [33]. The redox potential is more electro negative, $\mathrm{Eh}=-300 \ldots-414 \mathrm{mV}$ during hydrogen fermentation $[6,34]\left(\mathrm{C}_{6} \mathrm{H}_{12} \mathrm{O}_{6}+2 \mathrm{H}_{2} \mathrm{O}=\right.$ $\left.2 \mathrm{CH}_{3} \mathrm{COOH}+2 \mathrm{CO}_{2}+4 \mathrm{H}_{2}[10,6]\right)$. 
The efficiency of redox reactions is determined by the potential difference between donor and acceptor systems. Low-potential hydrogen fermentation is more effective for reduction of both $\mathrm{CrO}_{4}{ }^{2-}$ and $\mathrm{Cu}^{2+}$ (Fig. 2). The potential difference between cytochromes and chromate is $355 \mathrm{mV}$, and between hydrogenases and chromate is $969 \mathrm{mV}$. Similar patterns are for the reduction of $\mathrm{Cu}^{2+}$ by microorganisms. Thus, the potential difference between cytochromes and $\mathrm{Cu}^{2+}$ is $300 \mathrm{mV}$, and between hydrogenase and $\mathrm{Cu}^{2+}$ is $914 \mathrm{mV}$.

Hence, it is obvious that hydrogen dark fermentation is the most effective metabolic pathway for the biotechnology of purification of industrial

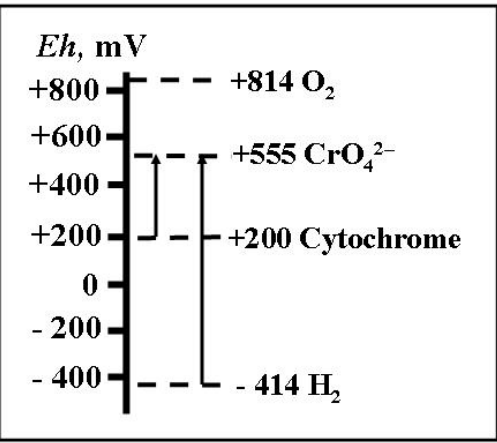

wastewater containing $\mathrm{CrO}_{4}{ }^{2-}$ and $\mathrm{Cu}^{2+}$. Of course, the use of glucose as a donor substrate is unprofitable and impossible. However, food and other waste containing polymeric carbohydrates (for example, starch, cellulose, etc.) are suitable for biotechnology. Hydrolysis of such waste under anaerobic conditions leads to the formation of soluble carbohydrates (including glucose) and further to the rapid and effective reduction of chromium and copper ions to insoluble compounds:

$$
\begin{gathered}
\mathrm{CrO}_{4}{ }^{2-}+(\mathrm{n}-1) \mathrm{H}_{2} \mathrm{O}+5 \mathrm{H}^{+}+3 \mathrm{e}=\mathrm{Cr}(\mathrm{OH})_{3} \cdot \mathrm{nH}_{2} \mathrm{O}[35], \\
2 \mathrm{Cu}^{2+}+\mathrm{H}_{2} \mathrm{O}+2 \mathrm{e}=\mathrm{Cu}_{2} \mathrm{O}+2 \mathrm{H}^{+}[29] .
\end{gathered}
$$

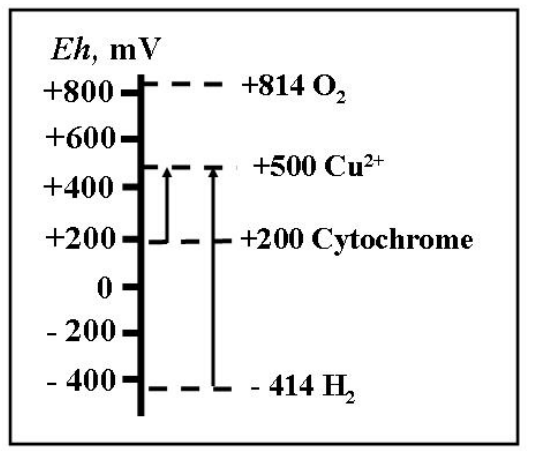

Fig. 2. Effectiveness of microbial reduction of toxic metals

The efficiency of metal removal can be increased by the presence of protein compounds. For hydrogensynthesizing anaerobes, proteins are additional electron donors, as well as precursors of alkaline compounds, which increase copper deposition efficiency due to the formation of $\mathrm{Cu}(\mathrm{OH})_{2}$ and $\mathrm{CuCO}_{3}$. Multi component food waste of megacities are almost unlimited sources of polymeric compounds of carbohydrates and proteins. Given the fact that anaerobic fermentation of polymers leads to their hydrolysis (i.e. destruction), it is obvious that two positive environmental processes can be combined in industrial biotechnologies: destruction of environmentally hazardous organic compounds and removal of toxic metals from wastewater. The third positive effect of biotechnology is the formation of environmentally friendly energy carrier - molecular hydrogen, as well as a valuable product - metal concentrate.

It should be emphasized that, at first glance, the growth of low-potential hydrogen-synthesizing bacteria $(E h=-400 \ldots-414 \mathrm{mV})$ is not possible in the presence of high-potential $\mathrm{CrO}_{4}{ }^{2-}(\mathrm{Eh}=+555 \mathrm{mV})$ and $\mathrm{Cu}^{2+}(\mathrm{Eh}=+500 \mathrm{mV})$. High-potential metals must inevitably suppress the growth of obligate anaerobic microorganisms. Nevertheless, the simultaneous occurrence of these processes is possible creating a stereometric gradient of the redox potential in a heterophase system (Fig. 3).

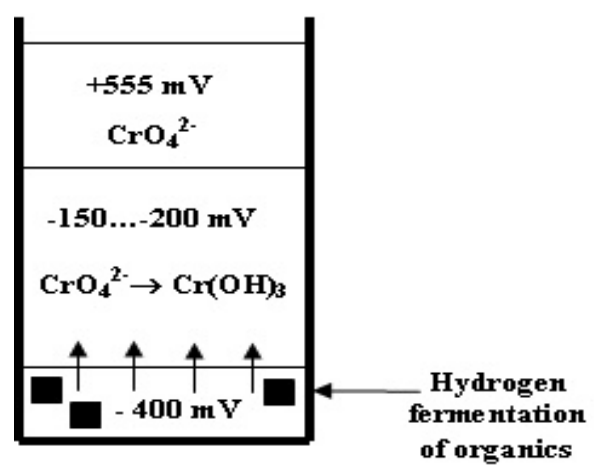

Fig. 3. Combination of hydrogen fermentation of organics and reduction of $\mathrm{CrO}_{4}{ }^{2-}$ 
Solid particles of food waste at the bottom of the cultivator with facultative and obligate anaerobic hydrogen-synthesizing microorganisms immobilized on them create an anaerobic zone with a local redox potential in the solid phase $-300 \ldots-400 \mathrm{mV}$. This anaerobic zone is not available for the solution of high-potential chromium due to diffusion difficulties, and also due to the "flow" of reduced low-potential exometabolites formed during the hydrolysis of solid organic compounds. The gas bubbles formed during hydrogen fermentation facilitate the rapid transport of reductants into the chromate solution, and its rapid and unavoidable reduction to insoluble chromium(III) hydroxide. Such regularities are similar to $\mathrm{Cu}^{2+}$.

Fig. 3 shows that a stereometric gradient of the redox potential from $-400 \mathrm{mV}$ in the bottom zone to $+555 \mathrm{mV}$ in the upper zone should be created in the heterophase redox system. It is obvious that rapid and effective reduction of chromates by the products of anaerobic metabolism will occur in the middle zone with an assumed integral redox potential about $-150 . .-$ $200 \mathrm{mV}$.

Thus, on the basis of the thermodynamic prognosis of microbial interaction with toxic metal-oxidizers $\mathrm{CrO}_{4}{ }^{2-}$ and $\mathrm{Cu}^{2+}$, we have determined the necessary and sufficient conditions for effective biotechnology of industrial sewage treatment.

1. Reduction of metals to insoluble forms is carried out by obligate anaerobic microorganisms.
2. Multi component food waste are the most suitable substrates for this process.

3. The maximum efficiency of metal removal is achieved through the creation of a heterophase system.

We have experimentally confirmed the above mentioned theoretical positions (Fig. 4).

Fig. 4a shows the dynamics of fermentation of the model substrate and the conjugate reduction of chromate. During the first 2.5 days the growth of microorganisms and reduction of chromate are absent. At the same time, there is an adaptive decrease in the redox potential of medium from $+525 \mathrm{mV}$ to +360 $\mathrm{mV}$. Apparently, at this time facultative anaerobic microorganisms reduce dissolved oxygen and release the reduced exometabolites into the medium. After 2.5 days of cultivation, the growth of microorganisms begins simultaneously with the decrease of redox potential and concentration of $\mathrm{Cr}(\mathrm{VI})$. Apparently, the growth of microorganisms at a high redox potential in the solution $(+360 \mathrm{mV})$ is explained by the fact that anaerobic microorganisms created a local redox about $-300 \ldots-400 \mathrm{mV}$ during 2.5 days in the solid phase at the bottom of the vial. Then, in accordance with the above theoretical model, the reduced exometabolites entered the upper zone, into the chromate solution, and quickly reduce it. It is evidenced by decrease in the redox potential from $+360 \mathrm{mV}$ to $-300 \mathrm{mV}$ correlated with a decrease in the chromate concentration. After 6 days of cultivation, the concentration of $\mathrm{Cr}(\mathrm{VI})$ decreased from $5000 \mathrm{ppm}$ to an analytical zero [15].
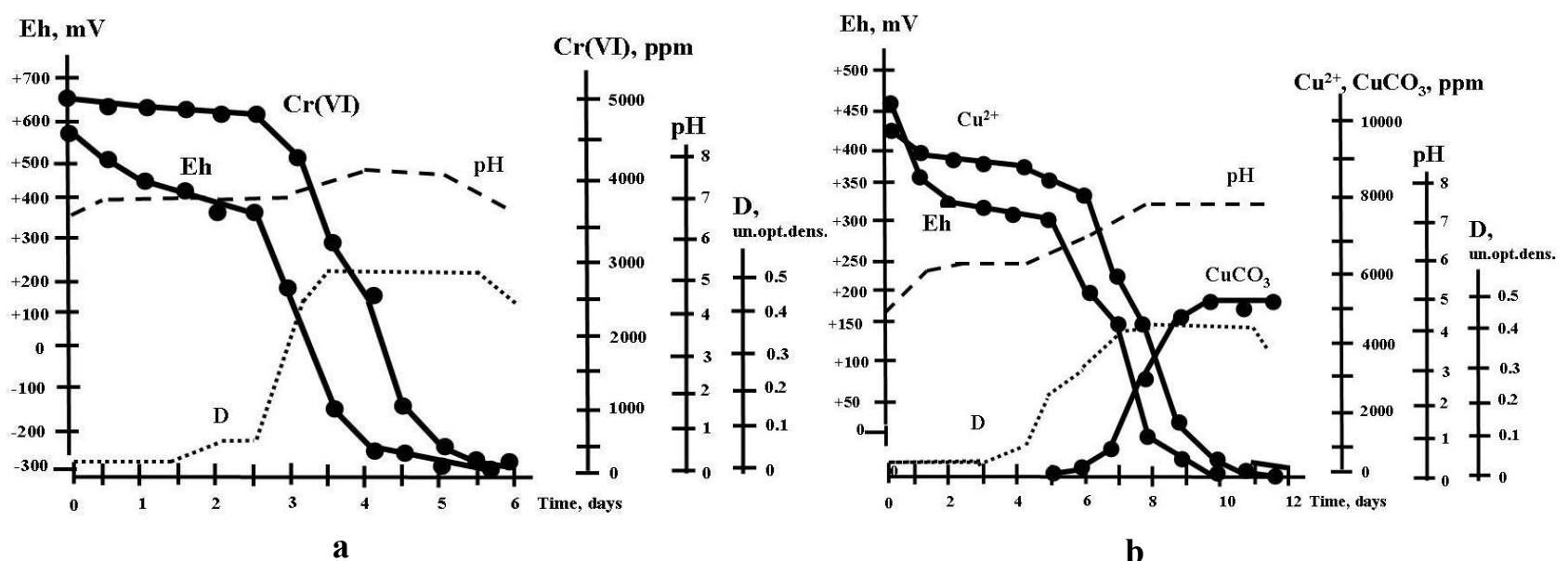

Fig. 4. Effectiveness of microbial removal of $\mathrm{CrO}_{4}{ }^{2-}$ and $\mathrm{Cu}^{2+}$ from solution

Similar patterns of interaction of anaerobic microorganisms with $\mathrm{Cu}^{2+}$ in the heterophase system are shown in Fig. 4b. So, for the first 5 days there is an adaptation of microorganisms and a gradual decrease in the redox potential of the medium from $+480 \mathrm{mV}$ to $+350 \mathrm{mV}$. After 5 days of cultivation, a sharp decrease in the redox potential from $+350 \mathrm{mV}$ to $-50 \mathrm{mV}$ leads to a correlative rapid decrease in the concentration of $\mathrm{Cu}^{2+}$. During 12 days of cultivation, the concentration of $\mathrm{Cu}^{2+}$ decreases from $10000 \mathrm{ppm}$ to zero. 
The thermodynamic prognosis indicates inevitable reduction of $\mathrm{Cu}^{2+}$ to $\mathrm{Cu}_{2} \mathrm{O}$ under anaerobic conditions. However, in this heterophase system, a direct analytical determination of reduced by microorganisms $\mathrm{Cu}(\mathrm{I})$ is impossible, since insoluble $\mathrm{Cu}_{2} \mathrm{O}$ compound is formed at the bottom of the vial. Indirect evidence of $\mathrm{Cu}^{2+}$ removal from the solution due to microbial reduction is the decrease of the redox potential to -50 $\mathrm{mV}$, as well as the formation of a loose layer of brown precipitate specific to $\mathrm{Cu}_{2} \mathrm{O}$ at the bottom of the vial.

Unlike chromates, the interaction of microorganisms with $\mathrm{Cu}^{2+}$ consists not only of the reduction of $\mathrm{Cu}^{2+}$, but also of the formation of insoluble $\mathrm{CuCO}_{3}$. So, the concentration of $\mathrm{CuCO}_{3}$ increases in the medium after 5 days, and at the end of cultivation it reaches $5800 \mathrm{ppm}$. An increase in the concentration of $\mathrm{CuCO}_{3}$ correlated with an increase in the $\mathrm{pH}$ of the medium. Consequently, we can assume that $\mathrm{Cu}^{2+}$ at the concentration of 4200 $\mathrm{ppm}$ microorganisms removed from the medium due to formation of insoluble $\mathrm{Cu}_{2} \mathrm{O}$, and the remaining part by precipitation in the form of $\mathrm{CuCO}_{3}$.

It should be emphasized that in galvanic and industrial wastewater the concentration of $\mathrm{Cr}(\mathrm{VI})$ is not more than 25-150 ppm [9, 21, 23]. Thus, the concentration of $\mathrm{Cr}(\mathrm{VI})$ in sewage of galvanic enterprises of Bangkok was determined to be $25 \mathrm{ppm}$ [39]. In our experiments, the initial concentration of $\mathrm{Cr}(\mathrm{VI})$ is $33 . . .200$ times higher, and yet obligate anaerobic microorganisms completely reduced chromate and removed it from the solution.

Similar patterns are also characteristic for copper containing wastewater. The concentration of copper in industrial sewage, as a rule, does not exceed 50-100 ppm [23].

At present, there are no microbial technologies that provide effective treatment of industrial sewage from copper in the concentration range of 200-500 ppm $\mathrm{Cu}^{2+}[24,13,4]$. The maximum resistance to copper is shown on the example of the strain Pseudomonas spp, which is resistant to $300 \mathrm{ppm} \mathrm{Cu}$ (II) [31] and three strains isolated from the "metal-bearing" river Mogpog, resistant to $15-390 \mathrm{ppm} \mathrm{Cu}^{2+}$ [26]. There are data about possibility of effective purification of industrial wastewater from $\mathrm{Cu}^{2+}$ compounds due to mechanisms of sorption by microbial cells $[17,30$, 25]. We showed that precipitation of $\mathrm{Cu}^{2+}$ by microorganisms in the form of $\mathrm{CuCO}_{3}$ and reduction to insoluble $\mathrm{Cu}_{2} \mathrm{O}$ are also very affective.

Chromium resistant microbial strains capable to accumulate and reduce chromium compounds were also isolated. Thus, soluble forms of $\mathrm{Cr}(\mathrm{VI})$ are converted into insoluble $\mathrm{Cr}$ (III) hydroxide, which is not harmful to both living organisms and the environment. Reduction is carried out by soluble reductases. Recently, two soluble Cr(VI) reductases, ChrR and YieF, have been purified from Pseudomonas putida MK1 and Escherichia coli, respectively. Direct application of $\mathrm{Cr}(\mathrm{VI})$ reductases may be a promising biotechnological approach for bioremediation of a wide range of contaminated environments [7]. Using initial $\mathrm{Cr}(\mathrm{VI})$ concentrations of 2 to $8 \mathrm{ppm}$ immobilized intact cells and the cell-free extracts Bacillus sp. ES 29 reduced 84 to $98 \%$ of the influent $\mathrm{Cr}(\mathrm{VI})$ [5]. Strain Vogococcus fluvialis isolated from contaminated industrial effluent was shown to carry out high efficiency in detoxification of dichromate by reducing it. These cells had high potential to reduce chromate to its non toxic trivalent form and could tolerate a maximum of $25 \mathrm{mM}$ chromate [22]. Also chromate reducing bacteria Pseudomonas aeruginosa strain MIE3 was isolated. It reduced 52\% of $150 \mathrm{ppm}$ potassium dichromate $(\mathrm{Cr}(\mathrm{VI}))$ in the nutrient broth after 24 hours incubation [16].

It is clear from this data that it becomes necessary to isolate significantly more resistant microorganisms for the purification of industrial sewage containing chromium and copper compounds in significantly higher concentrations [36].

In addition, despite the advent of modern environmental technologies, heavy metals are continuously accumulated in the environment, including chromium and copper. Our methodological approach, based on thermodynamic prognosis of microbial interaction with metals, allows not only to effectively neutralize their toxic forms, but also to obtain valuable concentrate of metals.

\section{CONCLUSIONS}

The biotechnology developed by us can ensure the purification of sewage from the compounds of chromium and copper with high efficiency. It can be assumed that the proposed biotechnology will also be effective for the purification of industrial wastewater from other toxic metals-oxidizers, for example, $\mathrm{Hg}(\mathrm{II}), \mathrm{V}(\mathrm{V}), \mathrm{U}(\mathrm{VI})$, etc. It will serve as the subject of our further research.

\section{REFERENCES}

1. Ahluwalia S. S., D. Goyal, Microbial and plant derived biomass for removal of heavy metals from wastewater, Biores. Technol., Vol. 98, 2007, 2243-2257.

2. Aziz H. A., A. Mojiri, editors. Wastewater Engineering: Advanced Wastewater Treatment Systems. IJSR Publications, 2014, 236 p. 
3. Borkow G., J. Gabbay, Copper as a biocidal tool, Current Medicin. Chem.,Vol. 12, No. 18, 2005, 2163-2175.

4. Cabrera G., R. Pérez, J.M.Gómez et. al., Toxic effects of dissolved heavy metals on Desulfovibrio vulgaris and Desulfovibrio sp. strains, J. Hazard Mater, Vol. 135, No. 1-3, 2006, 40-46.

5. Camargo F., B. Okeke, F. Bento et. al., Hexavalent chromium reduction by immobilized cells and the cell-free extract of Bacillus sp. ES 29, Bioremed. J., Vol. 8, No. 1-2, 2004, 23-30.

6. Cavalcante de Amorima E. L., A. R. Barrosb, M. H. R. Damianovicb et. al., Anaerobic fluidized bed reactor with expanded clay as support for hydrogen production through dark fermentation of glucose, Int. J. Hydrogen Energy, Vol. 34, No. 2, 2009, 783-790.

7. Cheung K.H., J.D. Gu, Mechanism of hexavalent chromium detoxification by microorganisms and bioremediation application potential: A review, Int. Biodeterior. Biodegrad., Vol. 59, No. 1, 2007, 8-15.

8. Cossich E. S., E. A. Da Silva, C. R. G. Tavares et. al., Biosorption of Chromium(III) by Biomass of Seaweed Sargassum sp. in a Fixed-Bed Column, Adsorp. J., Vol. 10, 2004, 129-138.

9. Dakiky M., M.Khamis, A. Manassra et. al., Selective adsorption of chromium(VI) in industrial wastewater using low-cost abundantly available adsorbents, Adv. Env. Res., Vol. 6, No. 4, 2002, 533-540.

10. Das D., N. Khanna, T. N., Veziroğlu, Recent developments in biological hydrogen production processes, Chem. Ind. Chem. Eng. Q., Vol. 14, No. 2, 2008, 57-67.

11. Dermentzis K., A. Christoforidis, E. Valsamidou, Removal of nickel, copper, zinc and chromium from synthetic and industrial wastewater by electrocoagulation, Int. J. Environ. Sci., Vol. 1, No.5, 2011, 697-710.

12. Garg U. K., M. P. Kaur, V. K. Garg et. al., Removal of hexavalent chromium from aqueous solution by agricultural waste biomas, J. Hazard. Mater., Vol. 140, 2007, 60- 68.

13. Gyawali R., S.A. Ibrahim, S.H.A. Hasfa et. al., Antimicrobial activity of copper alone and in combination with lactic acid against Escherichia coli o157:h7 in laboratory medium and on the surface of lettuce and tomatoes, Journal of Pathogens, Vol. 2011, 2011, 1-9.

14. Gottschalk G., Bacterial Metabolism, Springer-Verlag New York XIII, 1979, 359 p.
15. Greenberg A.E., L.S.Clesceri, A.D. Eaton, Standard methods for the examination of water and wastewater, $18 \mathrm{a}$ ed. 58-3.60, American Public Health Association, Washington, 1992, 187-190.

16. Halmi M. I. E., S. R. S. Abdullah, M. Y. Shukor, Characterization of Chromate Reducing Pseudomonas Aeruginosa Strain Mie3 Isolated from Juru River Sludge and its Potential on Azo Dye Decolorization, J. Chem. Pharmac. Sci., Vol. 10, No. 1, 2017, 522-526.

17. Ilhan S., M. N. Nourbakhsh, S. Kiliçarslan et. al., Removal of chromium, lead and copper ions from industrial waste waters by Staphylococcus saprophyticus, Turkish Electron. J. Biotechnol., Vol 2, 2004, 50-57.

18. Jaishankar M., T.Tseten, N. Anbalagan et. al., Toxicity, mechanism and health effects of some heavy metals, Interdiscip. Toxicol., Vol. 7, No. 2, 2014, 60-72.

19. Kanwar J.S., M.S. Sandha, Waste water pollution injury to vegetable crops - a revive, Agric. Rev., Vol. 21, No. 2, 2000, 133-136.

20. Knowles R., Denitrification, Microbiol. Rev., Vol. 46, No. 1, 1982, 43-70.

21. Kongsricharoern N., Application of Electrochemical Precipitation of Treatment of $\mathrm{Cr}$ Wastewater, Asian Institute of Technology (Doctoral Thesis), Bangkok, 1994.

22.Mistry K., C. Desai, K.Patel Chromate Reduction by Vogococcus sp. Isolated from Cr (VI) Contaminated Industrial Effluent, Electron. J. Biol., Vol. 6, No. 1, 2010, 6-12.

23. Monser L., N. Adhoum, Modified activated carbon for the removal of copper, zinc, chromium and cyanide from wastewater, Sep. Purif. Technolog., Vol. 26, 2002, 137-146.

24. Ochoa-Herrera V., G. León, Q. Banihani et. al., Toxicity of copper(II) ions to microorganisms in biological wastewater treatment systems. Sci Total Environ. Vol. 412-413, 2011, 380-385.

25. Ozdemir G., N. Ceyhan, T. Ozturk et. al., Biosorption of chromium(VI), cadmium(II) and copper(II) by Pantoea sp. TEM18, Chem. Engineer. J., Vol. 102, 2004, 249-253.

26. Parungao M.M., P.S. Tacata, C.R.G. Tanayan et. al., Biosorption of copper, cadmium and lead by copper-resistant bacteria isolated from Mogpog river, Marinduque. Philippine, Sci. J., Vol. 136, No. 2, 2007, 155-165.

27. Pepi M., F. Baldi, Modulation of chromium(VI) toxicity by organic and inorganic sulfur species in yeasts from industrial wastes, BioMetals, Vol. 5, No. 3, 1992, 179-185. 
28. Pourbaix M., Atlas of electrochemical equilibria in aqueous solutions (English edition), Pergamon press, Oxford, 1963, $320 \mathrm{p}$.

29. Prekrasna Ie. P., Tashyrev O. B., Copper resistant strain Candida tropicalis romcu5 interaction with soluble and insoluble copper compounds, Biotechnol. Acta, V. 8, No 5, 2015, 93-102.

30. Price M. S., J. J. Classen, G. A. Payne, Aspergillus niger absorbs copper and zinc from swine wastewater, Bioresour, Technol., Vol. 77, 2001, 41-49.

31. Rajbanshi A., Study on heavy metal resistant bacteria in guheswori sewage treatment plant. Our nature, Vol. 6, 2008, 52-57.

32. Samanovic M.I., C. Ding, D.J. Thiele et. al., Copper in microbial pathogenesis: meddling with the metal. Cell Host Microbe, 2012, Vol. 11, No. 2, 2012, 106-115.

33. Shlegel G., General microbiology, Mir, Moskva 1987, 567 p. (in Russian).

34. Tashyreva H., O. Tashyrev, V. Govorukha et. al. The effect of mixing modes on biohydrogen yield and spatial ph gradient at dark fermentation of solid food waste. Ecol. Eng. Env. Prot., Vol. 2, 2017, 53-62.

35. Tashyrev O.B., Ie.P. Prekrasna, G.O. Tashyreva et. al., Method of thermodynamic prognosis for new environmental biotechnologies development, J. Int. Sci. Publ., Vol. 1, No. 2, 2013, 92-110.

36. Tashyrev O.B., E.V. Halynker, E.Y Andreiuk, Thermodynamic prognosis of redox interaction of microorganisms with oxidizing metals $\left(\mathrm{Hg}^{2+}, \mathrm{CrO}_{4}{ }^{2-}\right.$ and $\left.\mathrm{Cu}^{2+}\right)$, Rep. of the NAS of Ukraine, No. 4., 2008, 166-172. (in Russian).

37. Tchounwou P.B., C.G.Yedjou, A.K.Patlolla et. al., Heavy Metal Toxicity and the Environment., Molec. Clin. Environ. Toxicol., Vol 101, 2012, 133-164.

38. Vymazal J., Removal of nutrients in various types of constructed wetlands. Sci. Total Environ., Vol. 380, 2007, 48-65.

39. Wong K.K., C. K. Lee, K.S Low et. al., Removal of $\mathrm{Cu}$ and $\mathrm{Pb}$ from electroplating wastewater using tartaric acid modified rice husk, Procces Biochem., Vol. 39, No. 4, 2003, 437-445.

\title{
ТЕРМОДИНАМИЧНО ДОКАЗВАНЕ НА ИНТЕГРАЛНИ МЕХАНИЗМИ ЗА МИКРОБИАЛНО ВЗАИМОДЕЙСТВИЕ С МЕТАЛИ
}

\author{
Вира Говоруха, Олеся Хаврилюк, Хана Таширева, Олександър Таширев, Ирина Сиома
}

Резюме: Въпреки нарастващия интерес към приложението на микроорганизмите за пречистване на отпадъчни води, съдържащи метали, досега микробните биотехнологии в тази област не са широко използвани поради тяхната емпирична основа. Ето защо целта на нашата работа е насочена към разработване на оптималните условия за отстраняване на токсични метали $\left(\mathrm{CrO}_{4}{ }^{2-}, \mathrm{Cu}^{2+}\right)$ с микроорганизми на базата на термодинамична прогноза и нейната експериментална обосновка. Получени са теоретични доказателства за експериментално потвърдено взаимодействие между микроорганизмите и редукцията или утаяването на металите. Разработеният подход е методологична основа за бързо и ефективно пречистване на отпадъчните води, съдържащи метали.

Ключови думи: термодинамична прогноза, токсични метали, отпадъчни води, редукцията на метали, утаяване на метали

\section{Researcher Vira Hovorukha, PhD}

Zabolotny Institute of Microbiology and Virology of the NAS of Ukraine, Department of Extremophilic Microorganism Biology, room 224

Address: Zabolotny str., 154, Kyiv, 03143, Ukraine

tel,: +380445263297

e-mail: vira-govorukha@ukr.net

\section{Leading engineer Olesia Havryliuk}

Zabolotny Institute of Microbiology and Virology of the NAS of Ukraine, Department of Extremophilic Microorganism Biology, room 224

Address: Zabolotny str., 154, Kyiv, 03143, Ukraine

tel,: +380445263297

e-mail: gav_olesya@ukr.net 


\section{Postdoc, principal investigator Hanna Tashyreva, $\mathrm{PhD}$}

Zabolotny Institute of Microbiology and Virology of the NAS of Ukraine, Department of Extremophilic Microorganism Biology, room 227

Address: Zabolotny str., 154, Kyiv, 03143, Ukraine

e-mail: anna.tashyreva@,gmail.com, hanna.tashyreva@upnm.edu.my

\section{Principal investigator Prof. Oleksand Tashyrev, Head of the Department}

Zabolotny Institute of Microbiology and Virology of the NAS of Ukraine, Department of Extremophilic Microorganism Biology, room 224

Address: Zabolotny str., 154, Kyiv, 03143, Ukraine

tel,: +380445263297

e-mail: tach2007@ukr.net

\section{Leading engineer Iryna Sioma}

Zabolotny Institute of Microbiology and Virology of the NAS of Ukraine, Department of Extremophilic Microorganism Biology, room 224

Address: Zabolotny str., 154, Kyiv, 03143, Ukraine

tel,: +380445263297

e-mail: irasioma82@gmail.com 